GENERASI EMAS

Jurnal Pendidikan Islam Anak Usia Dini

Vol. 01 No. 02, Oktober 2018

\title{
MENINGKATKAN KREATIVITAS MELALUI METODE PEMBERIAN TUGAS MELIPAT KERTAS PADA SISWA KELOMPOK B TK ISLAM YLPI MARPOYAN PEKANBARU
}

\author{
AULIA AKMAL \\ TK Islam YLPI Pekanbaru \\ J1. Kaharuddin Nasution Marpoyan, Pekanbaru \\ auliaakmal68@yahoo.com
}

\begin{abstract}
Kindergarten is an educational institution intended for children aged 4-6 years to carry out a learning process so children can develop their potential early on. Children must obtain their motor, intellectual, social and emotional stimuli according to their age level. From an early age, children are introduced to folding paper. In kindergarten learning, most teachers pay less attention to children's learning outcomes towards this one learning. Teachers often use paper folding as a relaxation learning for children who pay less attention to children's learning outcomes towards this one learning. Teachers often use paper folding as a relaxation study for children regardless of the results of children's work so that it is found that children's work in learning to fold paper seems without direction. The purpose of this study was to find out that folding paper can increase children's creativity in the B3 Group of Islamic Kindergarten YLPI Marpoyan, Pekanbaru. This study is a Classroom Action Research (CAR) conducted in two cycles, in each cycle of three meetings. The results showed that the paper folding development activities in the B3 group with the assignment of tasks had succeeded and increased. Increasing children's creativity through paper folding activities can be seen in cycle II. Hand speed coordination with the eye in carrying out the activities between the hand and eye are interconnected, careful, concentration on the tasks of activities carried out by students at the time of the activity activities hope that the resulting work is better, neater and faster in completing.
\end{abstract}

Keywords: Creativity, Methods, Giving Duties, Covers Paper, Students

\section{PENDAHULUAN}

Setiap manusia memiliki potensi atau bakat kecerdasan, tanggung jawab pendidik untuk memupuk dan mengembangkan secara sistematis.
Sebagaimana yang tercantum dalam UUD 1945 adalah "Mencerdaskan Kehidupan Bangsa". Pendidikan di Taman Kanakkanak (TK) merupakan pendidikan yang menyenangkan dengan prinsip "Belajar 


\section{GENERASI EMAS}

Jurnal Pendidikan Islam Anak Usia Dini

Vol. 01 No. 02, Oktober 2018

sambil bermain, bermain seraya belajar". Mengamati

perkembangan

Berangkat dari sinilah pembelajaran yang

kognitif anak didik yang berkaitan dengan

ada di TK harus dicermati, sehingga apa yang diharapkan, yakni agar anak-anak lebih mandiri dalam segala hal sesuai dengan kapasitas anak bisa ditercapai. Metode pengajaran yang tepat dan cermat akan mengarahkan anak-anak pada hasil yang optimal.

Anak Taman Kanak-Kanak adalah sosok individu yang sedang dalam proses perkembangan. Perkembangan anak adalah suatu proses perubahan dimana anak belajar menguasai tingkat yang lebih tinggi dari aspek-aspek gerakan, berpikir, perasaan dan interaksi baik dengan sesama maupun dengan benda-benda dalam lingkungan hidupnya. Taman KanakKanak adalah lembaga pendidikan yang ditujukan bagi anak-anak usia 4-6 tahun untuk melaksanakan suatu proses pembelajaran agar anak dapat mengembangkan potensinya sejak dini. Anak harus memperoleh rangsangan motorik, intelektual, sosial serta emosionalnya sesuai dengan tingkat usianya. Hal ini menunjukkkan bahwa seluruh potensi dan kecerdasan serta dasar-dasar perilaku seseorang telah mulai terbentuk pada usia tersebut. perkembangan kognitif seperti baca tulis, mengenal angka, sains, konsep mengelompokkan, meningkatkan kreativitas. Kelima bidang pengembangan tersebut diberi stimulasi agar perkembangannya optimal sehingga anak akan mendapatkan ketrampilan hidupnya. Salah satu perkembangan kognitif adalah meningkatkan kreativitas sangatlah penting dalam kehidupan anak didik dan secara tidak langsung dapat meningkatkan prestasi belajar anak didik di tingkat pendidikan selanjutnya.

Sebagian besar lembaga pendidikan selalu mengutamakan kecerdasan intelektual (IQ) saja padahal kreativitas penting, sebab kreativitas dan inteligensi sama-sama berperan dalam prestasi belajar. Kreativitas yang tinggi dapat meningkatkan prestasi belajar. Kreativitas sangat dibutuhkan karena banyak permasalahan serta tantangan hidup yang menuntut kemampuan adaptasi secara kreatif dan kepiwaian dalam mencari pemecahan masalah yang imajinatif.

Menurut Husain, dkk (2002: 2) anak usia dini berada dalam lima tahun pertama yang disebut The Golden Years 


\section{GENERASI EMAS}

Jurnal Pendidikan Islam Anak Usia Dini

Vol. 01 No. 02, Oktober 2018

merupakan masa emas perkembangan

anak. Anak pada usia tersebut mempunyai potensi demikian besar untuk mengoptimalkan segala aspek perkembangannya termasuk perkembangan motoriknya sebagai perkembangan unsur kematangan dan pengendalian gerak tubuh.

Sejak usia dini, anak sudah dikenalkan dengan melipat kertas. Dalam pembelajaran di TK kebanyakan guru kurang memperhatikan hasil belajar anak terhadap pembelajaran yang satu ini. Guru sering menggunakan melipat kertas sebagai pembelajaran relaksasi pada anak tanpa memperhatikan hasil karya anak sehingga diperoleh hasil karya anak dalam pembelajaran melipat kertas terkesan tanpa arahan.

Kelas atau kelompok B3 berdasarkan hasil pengamatan sebagai guru kelas bahwa kemampuan anak dalam pengembangan kreativitasnya sebagian besar anak masih kesulitan terutama dalam kegiatan melipat, hal ini dapat dilihat dari hasil kegiatan anak. Untuk itu peneliti merasa tertarik untuk melakukan penelitian tentang kreativitas anak terutama kegiatan melipat kertas. Menurut pengamatan peneliti selama ini, kreativitas yang berkaitan dengan kegiatan melipat kertas pada Kelompok B3 TK Islam YLPI Marpoyan Pekanbaru masih belum maksimal. Untuk itu peneliti merasa tertarik untuk melakukan penelitian tentang kreativitas anak. Dalam penelitian ini yang perlu ditingkatkan adalah kreativitas dan hasil kegiatan melipat kertas.

Berdasarkan latar belakang masalah tersebut di atas, rumusan masalah dalam penelitian ini adalah: "apakah melipat kertas dapat meningkatkan kreativitas anak pada Kelompok B3 TK Islam YLPI Marpoyan Pekanbaru?”

Tujuan penelitian ini adalah untuk mengetahui bahwa dengan melipat kertas dapat meningkatkan kreativitas anak pada Kelompok B3 TK Islam YLPI Marpoyan Pekanbaru.

Manfaat yang dapat diperoleh dalam penelitian ini adalah: (1) Bagi anak didik, agar siswa dapat percaya diri dalam menyelesaikan tugasnya, siswa dapat mencurahkan imajinasinya sesuai keinginan tanpa takut salah, siswa jadi termotivasi dalam pembelajaran yang meningkatkan kreativitasnya dan siswa dapat meningkatkan prestasi belajarnya secara optimal. (2) Bagi pendidik, untuk menambah pengetahuan penulis, untuk menambah khasanah ilmu bagi pendidik 


\section{GENERASI EMAS}

Jurnal Pendidikan Islam Anak Usia Dini

Vol. 01 No. 02, Oktober 2018

di TK, untuk memotivasi para guru TK khususnya, agar terus berusaha memberikan model pembelajaran kepada anak didiknya jadi lebih menyenangkan, dan agar lebih kreatif dalam mengajar sehingga pembelajaran yang dilaksanakan tidak monoton dan dapat menyenangkan bagi anak. (3) Bagi sekolah, dapat menyelesaikan masalah pembelajaran yang terjadi di sekolah, dapat meningkatkan kreatif dan kinerja guru dalam mengajar sehingga dapat meningkatkan kualitas dan kuantitas pendidikan.

Menurut Munandar (1999: 6) kreativitas adalah kemampuan seseorang untuk melahirkan sesuatu yang baru baik berupa gagasan maupun karya nyata yang relatif berbeda dengan apa yang telah ada sebelumnya. Menurut Suratno (2005: 24) kreativitas merupakan bentuk aktivitas imajinatif yang mampu menghasilkan sesuatu yang bersifat asli atau original.

Dari beberapa sumber di atas, dapat disimpulkan bahwa kreativitas adalah kemampuan seseorang untuk menghasilkan sesuatu yang baru sesuai imajinasi atau khayalannya.

Menurut Nursisto (1999: 6-7), kemampuan belajar siswa jadi lebih baik jika kemampuan kreativitasnya juga ikut dilibatkan. Pada dasarnya semua siswa memiliki kreatif dalam dirinya yang harus dikembangkan agar hidup jadi semangat dan produktif. Kesadaran akan kemampuan kreativitas ini harus dilatih untuk memacu keberhasilan siswa demi menyongsong masa depan.

Hal ini sejalan dengan ungkapan Getzels, dkk (dalam Nursisto, 1999: 3435) yang mengemukakan dalam achievement test, siswa yang memiliki IQ tinggi hasilnya sama bagusnya dengan siswa yang memiliki kreativitas tinggi. Ibarat pepatah tiada rotan akar pun jadi, maksudnya tiada IQ tinggi tapi punya kreativitas tinggi akan sama manfaatnya.

Sumanto (2005: 39) anak yang kreatif cirinya, yaitu punya kemampuan berfikir kritis, ingin tahu, tertarik pada kegiatan/tugas yang dirasakan sebagai tantangan, berani mengambil resiko, tidak mudah putus asa, menghargai keindahan, mampu berbuat atau berkarya, menghargai diri sendiri dan orang lain.

Menurut Nursisto (1999: 33) kreativitas bukanlah sesuatu yang mandiri atau berdiri sendiri, atau bukanlah sematamata kelebihan yang dimiliki seseorang, lebih dari itu kreativitas merupakan bagian dari buah usaha seseorang. Kreativitas 


\section{GENERASI EMAS}

Jurnal Pendidikan Islam Anak Usia Dini

Vol. 01 No. 02, Oktober 2018

akan menjadi seni ketika seseorang melakukan kegiatan.

Kreativitas salah satu sumber dari keberbakatan. Keberbakatan mempunyai persamaan dengan genius karena keduanya berkaitan dengan kualitas intelektual, namun keberbakatan seperti halnya talent belum tentu terwujud dalam suatu karya unggul yang mendapat pengakuan universal. Jadi tidak semua anak berbakat merupakan anak genius, sedangkan anak yang cerdas lebih mengandung pengertian sebagai anak yang memiliki inteligensi dan kecerdasan yang tinggi.

Fungsi pengembangan kreativitas pada anak TK adalah sebagai berikut: Pertama, fungsi pengembangan kreativitas terhadap perkembangan kognitif anak. Melalui pengembangan kreativitas anak memperoleh kesempatan sepenuhnya untuk memenuhi kebutuhan berekspresi menurut caranya sendiri. Pemenuhan keinginan itu diperoleh anak dengan menciptakan sesuatu yang lain dan baru.

Kedua, fungsi pengembangan kreativitas terhadap kesehatan jiwa. Craig (dalam Nursisto, 1999:

mengemukakan hasil penelitian Maslow yang menunjukkan suatu kesimpulan bahwa segala sesuatu yang mendukung pembangunan kreativitas seseorang secara positif akan mempengaruhi kesehatan mentalnya.

Ketiga, fungsi pengembangan kreativitas terhadap perkembangan estetika. Disamping kegiatan-kegiatan berekspresi yang sifatnya mencipta, anak dibiasakan dan dilatih untuk menghayati bermacam-macam keindahan, seperti keindahan alam, lukisan, tarian, musik, dan sebagainya.

Melipat atau origami adalah suatu teknik berkarya seni/kerajinan tangan yang umumnya dibuat dari bahan kertas dengan tujuan untuk menghasilkan aneka bentuk mainan, hiasan, benda fungsional, alat peraga dan kreasi lainnya. Bagi anak usia Taman Kanak-Kanak, melipat merupakan salah satu bentuk kegiatan bermain kreatif yang menarik dan menyenangkan. Melalui kegiatan ini dapat mengembangkan kompetensi pikir, imajinasi, rasa seni dan ketrampilan anak. Secara khusus kegiatan melipat bertujuan untuk melatih daya ingatan, pengamatan, ketrampilan tangan, mengembangkan daya fantasi, kreasi, ketelitian, kerapian dan perasaan keindahan.

Melipat pada hakikatnya merupakan kegiatan ketrampilan tangan untuk menciptakan bentuk-bentuk tertentu 


\section{GENERASI EMAS}

Jurnal Pendidikan Islam Anak Usia Dini

Vol. 01 No. 02, Oktober 2018

tanpa menggunakan bahan perekat (lem).

Ketrampilan ini membutuhkan

ketrampilan koordinasi tangan, ketelitian

dan kerapian serta kreativitas kegiatan

melipat jika disajikan sesuai dengan minat

anak akan memberikan keasyikan dan kegembiraan serta kepuasan bagi anak (Sumantri, 2005: 150).

Melipat merupakan kegiatan yang dapat melatih daya ingatan, pengamatan dan melatih otot-otot tangan/jari, otot-otot mata termasuk koordinasinya dan ketrampilan tangan.

Langkah-Langkah pelaksanaan melipat kertas: a. Guru membagikan kertas kepada anak.

b. Guru memperlihatkan contoh dan menerangkan bentuk lipatan yang akan dibuat.

c. Guru memberi contoh cara melipat.

d. Anak-anak diberi kesempatan untuk melipat menurut contoh yang sudah jadi.

e. Anak diberi petunjuk dan bimbingan apabila diperlukan.

f. Guru menghargai dan memberi pujian dan nilai hasil karya anak. (Depdikbud, Pedoman Guru, Bidang Pengembangan Daya Cipta di TK, 1988: 32).

\section{Kerangka Pikir}

Bagan Kerangka Berpikir :

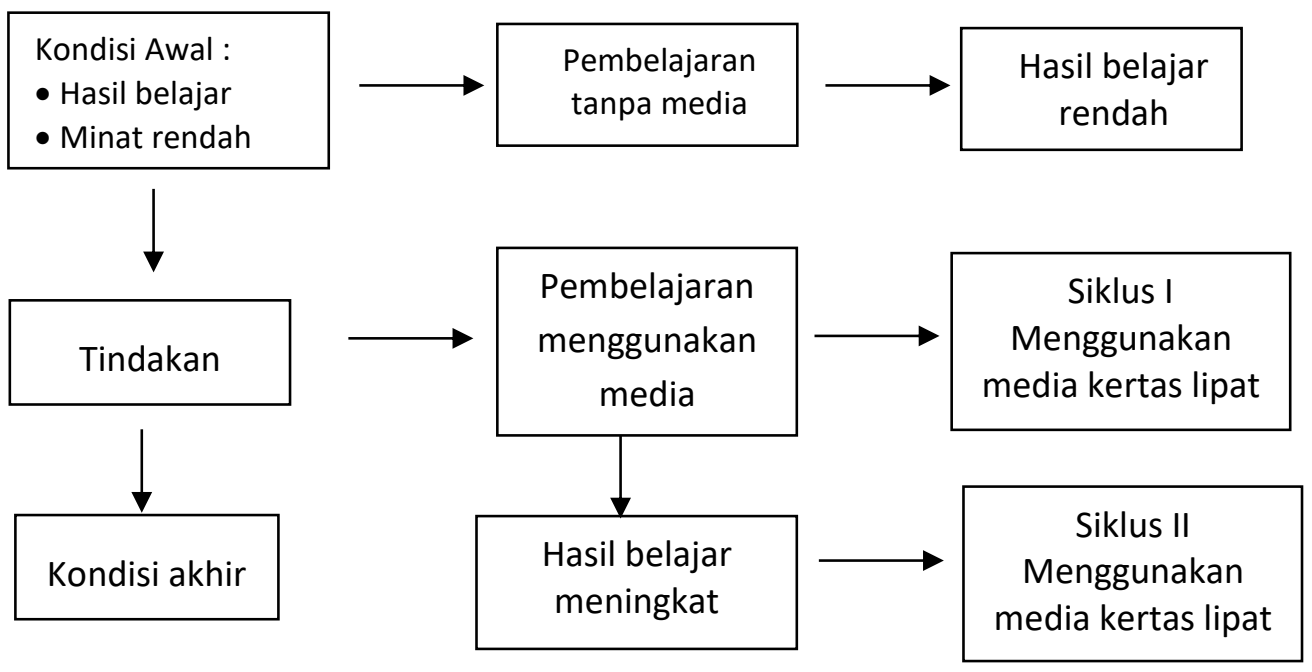


GENERASI EMAS

Jurnal Pendidikan Islam Anak Usia Dini

Vol. 01 No. 02, Oktober 2018

Kemampuan motorik halus anak melalui kegiatan melipat merupakan hasil belajar oleh faktor metode pembelajaran yang digunakan guru dalam mengajar.

Penggunaan metode pemberian tugas diharapkan dapat meningkatkan aktivitas kegiatan pembelajaran. Dengan media kertas diharapkan juga anak-anak akan senang dalam melaksanakan kegiatan ini.

\section{METODOLOGI PENELITIAN}

Subjek dalam penelitian ini adalah siswa kelompok B3 TK Islam YLPI Marpoyan Pekanbaru dengan jumlah 20 anak dengan rincian laki-laki 13 orang dan perempuan 7 orang dengan usia rata-rata 5 tahun. Pertimbangan penulis mengambil subjek penelitian tersebut dimana siswa kelompok B3 telah mampu dan memiliki kemandirian dalam membuat kreativitas dalam melipat kertas.

Penelitian ini mengambil lokasi di TK YLPI Pekanbaru, pemilihan lokasi atau tempat ini dengan pertimbangan penulis bekerja pada sekolah tersebut, sehingga memudahkan dalam mencari data, peluang waktu yang luas dan subjek penelitian yang sangat sesuai dengan profesi penulis.

Dengan beberapa pertimbangan dan alasan penulis menentukan menggunakan waktu penelitian selama satu minggu di bulan Agustus 2015. Waktu dari perencanaan sampai penulisan laporan hasil penelitian tersebut pada semester I tahun pelajaran 20152016. Waktu untuk melaksanakan tindakan pada bulan Agustus 2015, mulai dari siklus I dan Siklus II.

Tabel 1. Waktu Penelitian

\begin{tabular}{|c|c|c|c|}
\hline No & Siklus & Alokasi Waktu & Materi Kegiatan \\
\hline \multirow{3}{*}{1} & \multirow{3}{*}{ I } & $08.00-08.45$ & Melipat kertas bentuk kipas \\
\hline & & $08.00-08.45$ & Melipat kertas bentuk kipas \\
\hline & & $08.00-08.45$ & Melipat kertas bentuk kipas \\
\hline \multirow{3}{*}{2} & \multirow{3}{*}{ II } & $08.00-08.45$ & Melipat kertas bentuk baling-baling \\
\hline & & $08.00-08.45$ & Melipat kertas bentuk baling-baling \\
\hline & & $08.00-08.45$ & Melipat kertas bentuk baling-baling \\
\hline
\end{tabular}


GENERASI EMAS

Jurnal Pendidikan Islam Anak Usia Dini

Vol. 01 No. 02, Oktober 2018

Penelitian ini merupakan

Penelitian Tindakan Kelas (PTK) yaitu penelitian yang didasarkan pada permasalahan yang muncul dalam kegiatan pembelajaran. Prosedur penelitian yang diterapkan dalam hal ini antara lain :

1. Perencanaan

Meliputi penyampaian materi pelajaran, latihan soal, pembahasan latihan soal, tugas pekerjaan rumah (kegiatan penelitian utama) pembahasan PP, ulangan harian.

2. Tindakan/kegiatan mencakup

a. Siklus I, meliputi : Pendahuluan, kegiatan pokok dan penutup,

b. Siklus II (sama dengan I)

c. Siklus III (sama dengan I dan II)

3. Refleksi, dimana perlu adanya pembahasan antar siklus-siklus tersebut untuk menentukan kesimpulan atau hasil dari penelitian.

Instrumen yang digunakan pada penelitian ini adalah pedoman tes dan nontes. Pedoman tes berupa pedoman penilaian praktik keterampilan melipat kertas yang dilakukan anak. Sedangkan pedoman nontes berupa pedoman observasi dan wawancara.

Penelitian ini menggunakan dua teknik pengumpulan data, yaitu teknik tes dan nontes. Teknik tes yaitu tes keterampilan melipat kertas anak. Teknik nontes yaitu teknik observasi dan wawancara.

Teknik analisis data dilakukan secara kuantitatif dan kualitatif. Teknik kuantitatif digunakan untuk menganalisis data kuantitatif yang diperoleh dari hasil tes menggambar tematis anak. Teknik kualitatif digunakan untuk menganalisis data yang diperoleh dari observasi dan wawancara.

\section{HASIL DAN PEMBAHASAN}

Hasil penelitian ini menunjukkan bahwa sebelum dilakukan pembelajaran melipat kertas, anak berada pada kategori kurang karena cenderung meniru dan kurang adanya inisiatif serta kreatif. Untuk mengatasi kondisi tersebut, dilakukan Penelitian Tindakan Kelas (PTK) dengan menggunakan teknik melipat. Pelaksanaan penelitian ini dilaksanakan dalam dua siklus yang dalam setiap siklusnya masing-masing tiga pertemuan. Dalam siklus pertama meningkatkan kemampuan anak dalam melipat belum maksimal, sehingga peneliti melakukan kegiatan perbaikan dalam siklus kedua. Dalam siklus kedua peneliti lebih memfokuskan kemampuan 


\section{GENERASI EMAS}

Jurnal Pendidikan Islam Anak Usia Dini

Vol. 01 No. 02, Oktober 2018

anak dalam meningkatkan kemampuan

motorik halus dengan hasil yang sangat meningkat.

Pelaksanaan perbaikan dalam setiap siklus dapat dirinci sebagai berikut:

\section{Studi Awal}

Penelitian tindakan kelas studi awal ini rendah karena hasil kegiatan dalam melipat kurang berhasil, dari 20 anak yang diobservasi, siswa yang tidak berhasil ada 11 anak atau $55 \%$, yang berhasil dengan bantuan 6 anak atau $30 \%$, yang berhasil dengan mandiri ada 3 anak atau $15 \%$ karena pada studi awal yang berhasil masih sedikit maka peneliti merefleksi diri apa yang harus dilakukan agar dalam meningkatkan kemampuan motorik halus melalui metode pemberian tugas melipat kertas lebih berhasil.

\section{Siklus I}

Siklus I peneliti menyediakan alat peraga dan mengadakan tanya jawab tentang bentuk benda apa saja yang dapat dilipat. Peneliti sudah menyiapkan alat peraga yang akan digunakan dalam kegiatan pada waktu itu. Setelah siswa diberi pengarahan maka peneliti menerangkan cara melipat bentuk kipas, anak-anak diberi tugas untuk menirukan cara melipat. Kegiatan yang sudah dilakukan anak-anak menunjukkan bahwa hasil yang dicapai dalam meningkatkan kreativitas melalui metode pemberian tugas masih belum maksimal, maka peneliti menindaklanjuti kegiatan pada siklus II.

\section{Siklus II}

Pada siklus II peneliti berusaha untuk lebih meningkatkan kreativitas anak melalui kegiatan melipat kertas. Peneliti memberikan semangat dan pengarahan agar anak dapat menyelesaikan tugas yang diberikan. Untuk mencapai tujuan dalam penelitian maka peneliti selalu memberikan perhatian dan menjawab setiap pertanyaan yang diajukan anak terkait dengan kegiatan yang sedang dilakukan. Dengan pengarahanpengarahan yang diberikan dan mengulang cara melipat, maka pemahaman anak tambah baik, dengan demikian maka kegiatan yang dilakukan berhasil baik.

Adapun hasil pelaksanaan penelitian pada tiap-tiap siklus sebagai berikut:

1. Siklus I

Adapun langkah-langkah yang dilakukan guru pada tahap ini adalah sebagai berikut:

a. Guru menyiapkan alat peraga 
GENERASI EMAS

Jurnal Pendidikan Islam Anak Usia Dini

Vol. 01 No. 02, Oktober 2018

b. Guru memperlihatkan contoh peraga yang sudah jadi

c. Guru membagikan alat peraga

d. Guru menjelaskan dan memberikan contoh cara melipat

e. Guru memberikan tugas kepada anak untuk melipat kertas sesuai dengan contoh yang diberikan

f. Guru memberikan bimbingan pada anak yang membutuhkan

g. Guru memberikan penilaian hasil karya anak.

Pelaksanaan kegiatan pembelajaran dilaksanakan sebagai berikut:

a. Pertemuan Pertama

Kegiatan awal berdoa, menyanyi mars TK, kemudian dilanjutkan dengan kegiatan inti menjelaskan tentang kegiatan melipat bentuk kipas. Setelah selesai melaksanakan kegiatan prosentase keberhasilannya adalah: tidak berhasil 9 anak (45\%), berhasil dengan bantuan 6 anak (30\%), berhasil dengan mandiri 5 anak (25\%). Karena hasil yang diperoleh belum maksimal maka dilakukan perbaikan pembelajaran pada pertemuan kedua.

b. Pertemuan Kedua

Pada pertemuan kedua peneliti melakukan perbaikan dengan metode pemberian tugas. Melalui kegiatan tersebut siswa berusaha melaksanakan tugas dengan lebih baik sehingga hasil kegiatan meningkat. Anak yang tidak berhasil 7 anak (35\%), berhasil dengan bantuan 7 anak (35\%), berhasil dengan mandiri 6 anak (30\%). Karena hasil kegiatan belum maksimal maka perbaikan pembelajaran dilanjutkan pada pertemuan ketiga.

c. Pertemuan Ketiga

Pada pertemuan ketiga peneliti melakukan perubahan proses pembelajaran sehingga hasil melipat kertas anak bertambah. Anak yang tidak berhasil 6 anak (30\%), berhasil dengan bantuan 7 anak (35\%), berhasil dengan mandiri 7 anak $(35 \%)$.

\section{d. Refleksi}

Pada kegiatan melipat bentuk kipas yang berkaitan dengan kreativitas anak yang berhasil dengan mandiri masih rendah. Untuk itu dilakukan perbaikan pembelajaran agar hasil kegiatan meningkat. Pada siklus I anak yang berhasil dengan mandiri masih di bawah 50\% maka perbaikan dilanjutkan pada siklus II. 
GENERASI EMAS

Jurnal Pendidikan Islam Anak Usia Dini

Vol. 01 No. 02, Oktober 2018

2. Siklus II

Pelaksanaan kegiatan berikutnya dilaksanakan 3 (tiga) kali pertemuan.

Dalam pelaksanaan kegiatan, guru menyiapkan alat peraga serta melakukan langkah-langkah, seperti yang dilakukan pada Siklus I. Pembelajaran pada siklus kedua anak melaksanakan kegiatan melipat bentuk baling-baling. Kegiatan tersebut dilaksanakan pada pertemuan keempat.

a. Pertemuan keempat

Pada pertemuan keempat peneliti melakukan proses perubahan pembelajaran ternyata hasil kegiatan anak meningkat. Anak yang tidak berhasil 5 anak (25\%), berhasil dengan bantuan 5 anak (25\%), berhasil dengan mandiri 10 anak (50\%).

b. Pertemuan kelima

Pada pertemuan kelima peneliti melakukan perubahan proses pembelajaran ternyata hasil kegiatan anak meningkat. Anak yang tidak berhasil 3 anak (15\%), berhasil dengan bantuan 4 anak (20\%), berhasil dengan mandiri 13 anak (65\%).

c. Pertemuan keenam

Pada pertemuan keenam peneliti melakukan perubahan proses pembelajaran ternyata hasil kegiatan anak meningkat. Hasilnya adalah tidak ada satupun anak yang tidak berhasil (0\%), berhasil dengan bantuan 3 anak (15\%), berhasil dengan mandiri 17 anak $(85 \%)$.

\section{d. Refleksi}

Perbaikan pembelajaran kreativitas melalui metode pemberian melipat kertas yang dilaksanakan dua siklus ternyata mampu meningkatkan pemahaman melipat. Keberhasilan itu dapat dilihat pada setiap siklusnya.

Siklus I peneliti mempersiapkan alat peraga dan penunjang lainnya untuk memudahkan dalam melaksanakan kegiatan belajar mengajar. Pelaksanaannya dilakukan dengan mengubah posisi tempat duduk yang semula klasikal menjadi dua kelompok. Dengan cara ini diharapkan siswa tidak mudah bosan dan senang dengan kegiatan yang dilakukan walaupun hasil kegiatan yang dilakukan siswa masih belum maksimal.

Kegiatan yang dilaksanakan pada siklus I pada pertemuan ke 1, 2, 3 dengan metode pemberian tugas melipat kertas bentuk kipas mempunyai tujuan untuk meningkatkan kreativitas anak. Sebelum kegiatan dimulai terlebih dahulu guru 
GENERASI EMAS

Jurnal Pendidikan Islam Anak Usia Dini

Vol. 01 No. 02, Oktober 2018

menyiapkan media yaitu berupa kertas lipat warna-warni.

Guru mengkondisikan anak dengan menata letak meja dan kursi secara berkelompok. Dengan penataan itu diharapkan guru mudah memantau kegiatan yang sedang berlangsung. Guru memberi penjelasan dan contoh cara melipat.

Pada siklus I masih banyak anak yang belum berhasil dikarenakan suasana kelas yang panas, ruang kelas yang sempit, serta ada siswa yang membuat gaduh suasana sehingga siswa yang lain menjadi terganggu. Disamping itu juga ada beberapa siswa yang tidak memperhatikan apa yang disampaikan guru saat kegiatan berlangsung.

Bagi yang berhasil karena tingkat kecerdasan bagus, selalu memperhatikan apa yang disampaikan guru dan betulbetul mengerjakan tugas yang diberikan guru. Hasil kegiatan yang dilaksanakan pada siklus I pada pertemuan 1, 2, 3 adalah 7 anak (30\%).

Pada pertemuan siklus I hasil kegiatan melipat belum maksimal, maka dilanjutkan pada siklus II dengan pertemuan 4, 5, dan 6. Dalam siklus II siswa melaksanakan kegiatan melipat bentuk baling-baling. Kegiatan ini kelanjutan dari siklus I sebagai pembelajaran siswa dalam meningkatkan kreativitas. Kegiatan perbaikan pembelajaran meningkatkan kreativitas. Perbaikan pembelajaran dalam meningkatkan kreativitas siswa melalui metode pemberian tugas melipat kertas.

Menurut peneliti dan pengamat telah berhasil walaupun belum mencapai seratus persen. Dengan kondisi ruang yang sempit dan panas guru tetap memberikan semangat, perhatian, contoh serta penjelasan secara jelas dan berulang. Faktor keberhasilan sangat diharapkan oleh peneliti, untuk itu peneliti akan berusaha melaksanakan kegiatan di luar ruangan agar lebih nyaman.

Faktor keberhasilan dan ketidakberhasilan hampir sama dengan kegiatan yang dilaksanakan pada siklus I. Walaupun demikian hasil kegiatan pada siklus II lebih meningkat dikarenakan siswa sudah melaksanakan kegiatan melipat pada siklus I. Hasil kegiatan melipat bentuk baling-baling pada siklus II adalah 17 anak (85\%).

Peningkatan kemampuan motorik halus dengan metode pemberian tugas melipat kertas pada siswa, antara lain:

a. Mampu mengembangkan kemampuan motorik halus yang berhubungan 
GENERASI EMAS

Jurnal Pendidikan Islam Anak Usia Dini

Vol. 01 No. 02, Oktober 2018

dengan ketrampilan gerak kedua tangan

b. Mampu menggerakkan anggota tubuh yang berhubungan dengan gerak jari jemari

c. Mampu mengkoordinasikan indra mata dan aktivitas tangan

d. Mampu mengendalikan emosi dalam beraktivitas motorik halus.

Selama kegiatan berlangsung dari siklus I sampai siklus II subyek yang kurang berhasil dikarenakan:

a. Kemampuan berbicara kurang lancar

b. Kemampuan daya tangkap di bawah teman-teman yang lain

c. Kondisi ekonominya yang pas-pasan

d. Sering bengong atau melamun.

Selain itu, setelah dilakukannya Penelitian Tindakan Kelas (PTK) ini, anak juga lebih antusias dan semangat dalam kegiatan melipat kertas. Hal ini dikarenakan anak telah memiliki daya imajinasi dan kreativitas yang lebih besar dari sebelumnya pada diri mereka.

\section{PENUTUP}

Berdasarkan hasil observasi dan analisis terhadap pelaksanaan kegiatan pembelajaran dapat disimpulkan sebagai berikut: Kegiatan pengembangan melipat kertas pada kelompok B3 dengan pemberian tugas telah berhasil dan meningkat. Peningkatan kreativitas anak melalui kegiatan melipat kertas terlihat pada siklus II. Koordinasi kecepatan tangan dengan mata di dalam melaksanakan kegiatan antara tangan dan mata saling keterkaitan, cermat, konsentrasi terhadap tugas kegiatan yang dilakukan siswa pada saat berlangsungnya kegiatan harapan karya yang dihasilkan lebih bagus, rapi dan cepat dalam menyelesaikan.

Mengingat pelaksanaan penelitian baru berjalan 2 siklus maka:

1. Guru TK diharapkan selalu membuka wawasan serta mengikuti perkembangan ilmu pengetahuan dan meningkatkan kreativitas sebagai pendidik.

2. Sekolah hendaknya menyediakan media yang berhubungan dengan kreativitas.

3. Peneliti hendaknya lebih kreatif dalam setiap melaksanakan kegiatan yang berhubungan dengan kreativitas. 
GENERASI EMAS

Jurnal Pendidikan Islam Anak Usia Dini

Vol. 01 No. 02, Oktober 2018

\section{DAFTAR PUSTAKA}

Departemen Pendidikan dan Kebudayaan.

1988. Pedoman Guru Bidang

Pengembangan Daya Cipta di

Taman Kanak-Kanak. Jakarta:

Depdikbud

Munandar, Utami. 1999. Kreativitas dan

Keberbakatan, Strategi

Mewujudkan Potensi Kreatif dan

Bakat: Gramedia Pustaka Utama.

Sumanto. 2005. Pengembangan

Kreativitas Seni Rupa Anak TK.

Jakarta: Depdiknas

Sumantri. 2005. Model Pengembangan Ketrampilan Motorik Anak Usia Dini. Jakarta: Departemen Pendidikan Nasional.

Suratno. 2005. Pengembangan Kreativitas

Anak Usia Dini. Jakarta: Depdiknas. 


\section{GENERASI EMAS}

Jurnal Pendidikan Islam Anak Usia Dini

Vol. 01 No. 02, Oktober 2018 